音声言語医学 $60 ： 196 － 204,2019$

\title{
内耳道狭窄を伴う人工内耳症例の検討
}

\begin{tabular}{|c|c|c|c|c|}
\hline 文子1,2) & 河野 & 淳1,2) & 野波 & 尚子 1,2$)$ \\
\hline 禎1,2) & 前田 & 沙知1, 2) & 白井 & 杏湖 1,2$)$ \\
\hline 陽子 1,2$)$ & 西山 & 信宏2,3) & 塚原 & 清彰1) \\
\hline
\end{tabular}

要 約: 小児の人工内耳は, 新生児聴覚スクリーニングの普及やその聴取, 言語力などの有 効性から増加の一途である。またそれに伴い, さまざまな難しい症例に施行され，特に内耳形 態異常症例に人工内耳が応用されている. 今回は, 当科で経験した内耳道狭窄を伴う人工内耳 装用 5 症例について検討した。その結果, マップでは全症例でパラメータを変更し電荷量を増 やす必要があった，全症例で音知覚が得られたが, 反応が出るまでに長期間を要する者が多く, 最長で 4 年半掛かった，全症例で語音聴取は不良であり，トータルコミュニケーションを使用 していた，術前に聴覚反応が少しでもあれば人工内耳の適応と考えられた。内耳道狭窄を伴う 症例の人工内耳植込み術にあたっては, 反応が見られるまでに時間が掛かること, 術後反応不 良の可能性があること, 人工内耳を介した会話には限界があることなどの術前の十分なイン フォームドコンセントと術後早期の適切なマップ作成が必要であると思われた.

索引用語：小児人工内耳, 新生児聴覚スクリーニング, 内耳道狭窄, 語音聴取, インフォー ムドコンセント

\section{Examination of Cochlear Implants with Stenosis of the Inner Ear Canal}
Ayako Tomizawa ${ }^{1,2)}$, Atsushi Kawano ${ }^{1,2)}$, Naoko Nonami ${ }^{1,2)}$, Sadamu Komatsu ${ }^{1,2)}$, Sachi Maeda ${ }^{1,2)}$, Kyoko Shirai ${ }^{1,2)}$, Yoko Ota ${ }^{1,2)}$, Nobuhiro Nishiyama ${ }^{2,3)}$ and Kiyoaki Tsukahara ${ }^{1)}$

\begin{abstract}
Cochlear implants for children are steadily increasing as an outgrowth of the spread of newborn hearing screening and the effectiveness of their usage. As a result, cochlear implants have come to be used even in various difficult cases, especially in patients with labyrinth morphological abnormalities.

We examined five cases in which cochlear implants were used in our department in patients with internal canal stenosis (ICS). In all cases, it was necessary to change parameters and increase the quantity of the electric charge. Sound perception was achieved in all cases, but in many cases a long period of time was required for a reaction to appear, the longest duration being four-and-a-half years. Because speech hearing was poor, we used
\end{abstract}

東京医科大学耳鼻咽喉科・頭頸部外科学分野 ${ }^{1)}$, 東京医科大学病院聴覚・人工内耳センター ${ }^{2)}$ ： $\overline{\text { T }} 160-0023$ 東京都新宿区西新宿 6-7-1

東京医科大学茨城医療センター耳鼻咽喉科 ${ }^{3)}$ : = 300-0395 茨城県稲敷郡阿見町中央 3-20-1

${ }^{1)}$ Department of Otolaryngology-Head and Neck Surgery, Tokyo Medical University, ${ }^{2)}$ Auditory and Cochlear Implant Center, Tokyo Medical University Hospital: 6-7-1, Nishishinjuku, Shinjuku-ku, Tokyo 160-0023, Japan

${ }^{3}$ Department of Otolaryngology, Tokyo Medical University Ibaraki Medical Center: 3-20-1, Chuo, Ami-machi, Inashiki-gun, Ibaraki 300-0395, Japan

2018 年 8 月 6 日受稿 2018 年 12 月 19 日受理 
total communication in all cases.

If there was even a slight preoperative improvement in hearing reaction, we considered this as an indication for cochlear implant.

In the case of cochlear implant surgery for children with ICS, we believe adequate conformed consent preoperatively is necessary in view of the lengthy amount of time required to achieve a reaction, the possibility of a poor reaction, and inherent limits to the degree of conversation achievable via cochlear implant. We also believe appropriate mapping needs to be performed as early as possible after surgery.

Key words: cochlear implants for children, newborn hearing screening, internal canal stenosis (ICS), speech hearing, informed consent

\section{はじめに}

小児の人工内耳は，患児の聴取，言語力などに大き な影響を及ぼし，その有効性について多くの報告があ る ${ }^{1,2)}$ 。さらに新生览聴覚スクリーニングの普及なと から小児の人工内耳手術症例が多くなっているなか, 1998 年に改定された日本耳鼻咽喉科学会による「人 工内耳適用基準」で小児への適応により「内耳奇形例 についても必ずしも禁忌にならない」とされたことに より ${ }^{3)}$,さまざまな内耳奇形（形態異常，以下内耳形 態異常とする）症例に人工内耳が応用されている.

一方，画像診断の進歩により詳細な内耳形態異常の 診断が可能となり，種々報告されている ${ }^{4,5)}$ ，従来， 内耳形態異常症例に対する人工内耳成績の報告の多く は, Sennaroglu と Saatci ${ }^{6,7)}$ の分類による報告が多く, 内耳道狭窄 (internal auditory canal stenosis, 以下 ICS）症例では, 補聴器で効果が得られないだけでは なく人工内耳の効果も期待できないと考えられ，禁忌 とする報告もあるように8)，しばしば contraindication とされることが多い，しかし，術前に全身 麻酔下で各種電気生理検查を行い, 人工内耳治療の適 応があると判断し，術後に良好な結果が得られた症例 もあり ${ }^{9)}$ ，実際には画像診断で内耳道狭窄，螖牛神経 低形成が疑われた症例でも，人工内耳の有効な症例も 報告されている10)

今回，われわれは当科で人工内耳植込み術を行った 小児内耳形態異常症例のなかで，ICS による高度難聴 と診断された 5 症例について, 術前の人工内耳適応評 価, 術後の問題, 音声言語の獲得などについて検討し たので報告する.

\section{対象と方法}

対象は，当科において 1985 年 12 月から 2017 年 4
月までに人工内耳の手術を施行した小児例 389 例中の 術前の CT または MRI 画像診断により両耳に ICS お よびその疑いが認められた 5 例。背景，術前評価とし ての聴力レベル (4 分法平均), 補聴器装用閾值 (4 分 法平均), Infant-Toddler Meaningful Auditory Intergration Scale（以下 IT-MAIS）, 聴性脳幹反応検査（以 下 $A B R$ ), 聴性定常反応検査 (以下 ASSR), 画像所 見について検討した。また手術所見，手術後経過とし てのマップ，人工内耳の装用閾值（4 分法平均）と聴 取 (IT-MAIS など), 発話, コミュニケーションモー ド，教育機関，認知発達および語彙発達について検討 した，画像所見については，内耳道の前後径を内耳道 内側部，中間部，入口部の 3 力所で測定して，その他 の内耳道形態異常についても検討したＩCS の診断は 内耳道の前後径が上記のいずれか，またはすべてで 3 $\mathrm{mm}$ 以下とした。

\section{術 前 評価}

対象の背景，画像結果を表 $1 ， 2$ に示す。現在の年 齢が 8 歳から 17 歳に及び, 平均で 12 歳 11 力月, 手 術時年齢が平均で 3 歳 2 カ月であった。いずれの手術 についても，ご家族の希望もあり施行している.

\section{1. 聴カレベル, 補聴器装用闇値, IT-MAIS} ABR および ASSR（表 1)

術前の聴力レベルはすべて $95 \mathrm{~dB}$ 以上，術前の補 聴器装用闇值は $60 \mathrm{~dB}$ から $90 \mathrm{~dB}$ 以上に及んでいた が，いずれも少なからず音への聴覚反応が確認され た。術前 ABR では症例 1 の右以外, ASSR では症例 3, 4，5 で一部無反応であった。 なお，症例 $1 ， 3$ に運動 発達障害の疑い，症例 2 は後に自閉症スペクトラムの 診断がなされ, 症例 3 に両側顔面神経麻痺, 症例 5 は ダウン症であった。術前に補聴器装用による反応は少 なからず見られたが，IT-MAIS は 10 点以下で，音声 
表 1 対象者の背景(術前)

\begin{tabular}{|c|c|c|c|c|c|c|c|c|c|c|}
\hline 症例 & $\begin{array}{l}\text { 現在の } \\
\text { 年齢 }\end{array}$ & $\begin{array}{l}\text { 紹介時 } \\
\text { 年齢 }\end{array}$ & $\begin{array}{l}\text { 手術時 } \\
\text { 年齢 }\end{array}$ & 術耳 & $\begin{array}{l}\text { 聴力レベル } \\
\text { (dBHL) }\end{array}$ & $\begin{array}{c}\text { 補聴器 (人工 } \\
\text { 内耳) 装用閾 } \\
\text { 值 }(\mathrm{dBHL})\end{array}$ & $\begin{array}{l}\text { IT- } \\
\text { MAIS }\end{array}$ & $\begin{array}{c}\mathrm{ABR} \\
(\mathrm{dBHL})\end{array}$ & $\begin{array}{l}\text { ASSR } \\
\text { (dBHL) }\end{array}$ & 参考 \\
\hline \multirow{3}{*}{1} & \multirow{3}{*}{17 歳 } & \multirow{3}{*}{$\begin{array}{l}1 \text { 歳 } \\
5 \text { カ月 }\end{array}$} & $\begin{array}{l}2 \text { 歳 } \\
6 \text { 力月 }\end{array}$ & 左 & $\begin{array}{l}\text { 右 } 110 \uparrow / \\
\text { 左 } 110 \uparrow\end{array}$ & 右 $75^{*}$ /左 $80^{*}$ & 2 & \multirow{3}{*}{ 105/NR } & \multirow{3}{*}{ 未検査 } & \multirow{3}{*}{$\begin{array}{l}\text { *補聴器にて } 1 \mathrm{kHz} \text { まで } 60 \\
\mathrm{~dB} \text { の反応あり. 右がやや良 } \\
\text { 好, **CI24RCS の認可によ } \\
\text { り, CI での反応が良い右に } \\
\text { 再手術施行. 運動発達, 言語 } \\
\text { の遅れあり }\end{array}$} \\
\hline & & & $\begin{array}{l}4 \text { 歳 } \\
10 \text { 力月 }\end{array}$ & 右 & $\begin{array}{l}\text { 右 } 110 \uparrow / \\
\text { 左 } 110 \uparrow\end{array}$ & (右 $40^{* *} /$ 左 $\left.50 * *\right)$ & 8 & & & \\
\hline & & & $\begin{array}{l}5 \text { 歳 } \\
3 \text { 力月 }\end{array}$ & 右 & - & - & - & & & \\
\hline \multirow{2}{*}{2} & \multirow{2}{*}{11 歳 } & \multirow{2}{*}{9 カ月 } & $\begin{array}{l}1 \text { 歳 } \\
8 \text { 力月 }\end{array}$ & 右 & $\begin{array}{l}\text { 右 } 100 / \\
\text { 左 } 100\end{array}$ & 右 $80 /$ 左 78 & 2 & \multirow{2}{*}{ NR/NR } & \multirow{2}{*}{$95 / 100$} & \multirow{2}{*}{ 右は左手術前に抜去 } \\
\hline & & & $\begin{array}{l}2 \text { 歳 } \\
8 \text { カ月 }\end{array}$ & 左 & 左 100 & 左 63.3 & 4 & & & \\
\hline 3 & 9 歳 & $\begin{array}{l}1 \text { 年 } \\
4 \text { 力月 }\end{array}$ & $\begin{array}{l}3 \text { 歳 } \\
1 \text { 力月 }\end{array}$ & 左 & $\begin{array}{l}\text { 右 } 95 / \\
\text { 左 } 100\end{array}$ & 右 60/ 左 75 & 9 & NR/NR & $\begin{array}{l}110 \uparrow / \\
110 \uparrow\end{array}$ & $\begin{array}{l}\text { 運動発達障害, 心内膜欠損症 } \\
\text { 術後, 顔面神経麻瘏 }\end{array}$ \\
\hline 4 & 8 歳 & $\begin{array}{l}1 \text { 年 } \\
4 \text { 力月 }\end{array}$ & $\begin{array}{l}3 \text { 歳 } \\
0 \text { 力月 }\end{array}$ & 右 & $\begin{array}{l}\text { 右 } 110 \uparrow / \\
\text { 左 } 110 \uparrow\end{array}$ & 右 88 / 左 95 & 2 & NR/NR & $\begin{array}{l}105 / \\
110 \uparrow\end{array}$ & \\
\hline 5 & 8 歳 & 9 カ月 & $\begin{array}{l}3 \text { 歳 } \\
9 \text { 力月 }\end{array}$ & 右 & $\begin{array}{l}\text { 右 } 106 / \\
\text { 左 } 110 \uparrow\end{array}$ & 右 79 / 左 90 & 3 & NR/NR & $\begin{array}{l}110 / \\
110 \uparrow\end{array}$ & ダウン症, 動脈管開存症 \\
\hline 平均 & $\begin{array}{l}12 \text { 歳 } \\
11 \text { 力月 }\end{array}$ & & $\begin{array}{l}3 \text { 歳 } \\
0 \text { カ月 }\end{array}$ & & & & & & & \\
\hline
\end{tabular}

·ABR, ASSR 結果は, 右/左で記載した.

・聴力レベルおよび補聴器 (人工内耳) 装用閾值は, $500 \mathrm{~Hz}, 1 \mathrm{kHz}, 2 \mathrm{kHz}$ での 4 分法平均閾值 (dBHL).

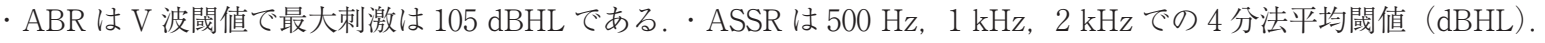

表 2 対象者の画像結果

\begin{tabular}{|c|c|c|c|c|c|}
\hline \multirow{2}{*}{ 症例 } & \multicolumn{4}{|c|}{$\mathrm{CT}$} & \multirow{2}{*}{$\begin{array}{c}\text { MRI } \\
\text { (蝸牛神経の確認) }\end{array}$} \\
\hline & 内耳道内側部 & 内耳道中間部 & 内耳道入口部 & その他内耳形態異常 & \\
\hline 1 & 右 1.04 / 左 1.23 & 右 1.78 / 左 1.98 & 右 $2.72 /$ 左 2.82 & 右前庭 ·半規管一部奇形 & 不明 \\
\hline 2 & 右 $3.07 /$ 左 3.25 & 右 1.98 / 左 2.50 & 右 2.7 / 左 3.85 & 右 IP-I & わずかにあり \\
\hline 3 & 右 2.30 / 左 2.02 & 右 2.35 / 左 2.41 & 右 $0.81 /$ 左 2.97 & & 不明 \\
\hline 4 & 右 2.98 / 左 3.86 & 右 2.93 / 左 4.14 & 右 5.18 / 左 4.75 & & 右不明 / 左あり \\
\hline 5 & 右 1.26 / 左 2.35 & 右 1.66 / 左 2.05 & 右 2.08 / 左 1.19 & 右前庭水平半規管奇形 & あり \\
\hline
\end{tabular}

表出はほとんど認めなかった.

症例 1 は, 補聴器での反応が少ない左側の手術を施 行し，反応が見られるまで約 1 年を要したが,さらに 聴力改善を目指し, 対側の右側にも手術を施行した. その後, CI24M で電極 7-19 に顔面痤攣が著明であっ たため, CI24RCSの認可により反応が良い右側に再 手術を施行した。症例 2 は, ASSR で右の反応が良かっ たことから, 最初 1 歳 8 力月時右に手術を施行した. しかし, 術後人工内耳による反応がなかなか認められ ず，保護者が 2nd opinion を希望し他院を受診した。 MRI 再撮影のためにマグネットを抜去, MRI での蝸 牛神経の確認をしたが, 他院での助言があり人工内耳
の電極自体も抜去し, 元々補聴器で低音域の反応が あった対側（左）に手術を施行した。その後，当科で も経過フォローとなった。症例 3 では紹介元病院では 反応が見られていたが, 紹介時当院では補聴器での反 応が全く見られなかった。徐々に補聴器での反応が見 られてきたが, 画像診断結果, 聴力検査結果, 家庭や 学校および病院における聴こえの様子, 内耳道狭窄等 による聴取不良の可能性，現状よりは音の入力可能な 可能性，手術によるリスク説明など慎重に適応評価を 行ったが, ご家族の強い希望もあり, 初診から 1 年 7 力 月後にCT画像にて内耳道が広いほうの左に手術し た。症例 4 は支援学校では $90 \mathrm{~dB}$ ほどの反応が，ま 
た病院でも当初 $90 \mathrm{~dB}$ 台の反応が見られたため慎重 に聴力検査を行ったが，手術前には裸耳では全く反応 が見られなかった。また，補聴器装用間值が平均で初 期に $70 \mathrm{~dB}$ ほど，手術前には $90 \mathrm{~dB}$ ほどの反応が見 られ，反応が良い右に初診から 1 年 8 力月たって手術 を施行した。症例 5 はダウン症であったため，適応判 定が難しく, 初診から 3 年を掛けて慎重に適応評価を

して，聴力レベルが良い右に手術を施行した。

\section{2 . 術前画像所見}

術前の画像所見の結果を表 2 に示す。撮影条件は, 内耳単純 MRI は ACPC ラインを基準に水平断，スラ イス幅 $0.7 \mathrm{~mm}$ の条件で撮影した。側頭骨単純 CT は OM ラインを基準に水平断，スライス幅 $0.675 \mathrm{~mm}$ の 骨条件で撮影したもので内耳道を計測した。全症例 CT 画像で内耳道の前後径が, 内耳道の内側部から入 口部までのいずれかで，0.81 から $5.18 \mathrm{~mm}$ に及び, 症例 4 の左以外はいずれかで $3 \mathrm{~mm}$ 以下で， ICS ある いはその疑いと診断した。症例 4 の左は必ずしも ICS と䛦断できていなかった。症例 4 は, 術前に補聴器で
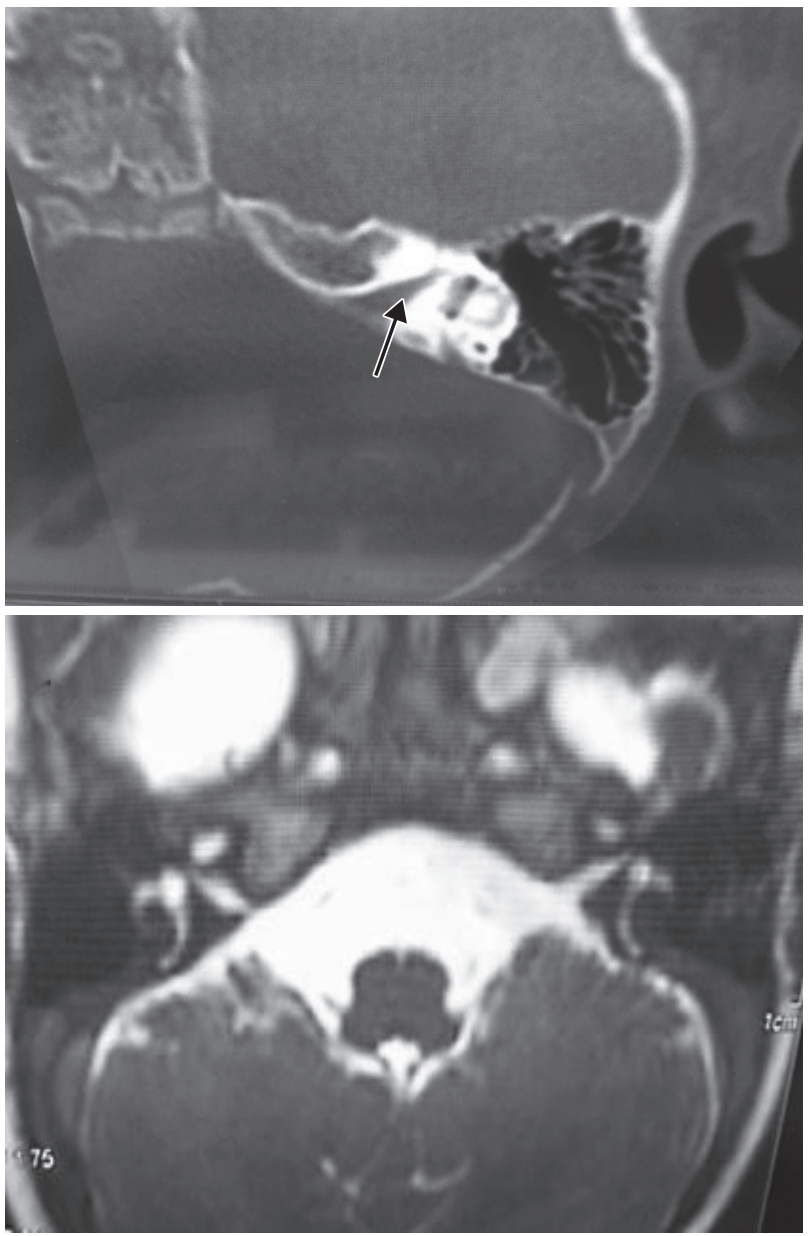

図 1 症例 3 の CT および $\mathrm{MR}$ 画像 矢印は内耳道狭窄を示す
右のほうが左よりも多少反応が見られていたため，右 に手術を施行しており，全症例でICSあるいはその 疑いのある耳に手術を施行している。症例 $1 ， 5$ では 前庭と半規管の形態異常も認められた。 MRI 画像で は, 症例 1,3,4 で蝸牛神経がはっきり確認できなかっ た。対象症例のうち症例 3,5 の画像を示す（図 1,2）。

\section{3. 術前適応診断}

全症例で，他覚的検査の結果も悪く，裸耳ではほほ $90 \mathrm{~dB}$ 以上の聴力レベルであること, 補聴器装用によ る音への反応はあるが十分とはいえないこと，かつ， ご家族の希望があったことから人工内耳植込み術と なった。手術にあたっては，画像診断結果を基に内耳 道狭窄等による聴取不良の可能性も含めていねいにイ ンフォームドコンセントを施行した。しかし，当初の 症例である症例 1 では, retrospective に見ると, 反 応が出るのに長期を要することの説明は十分といえな いと思われた。
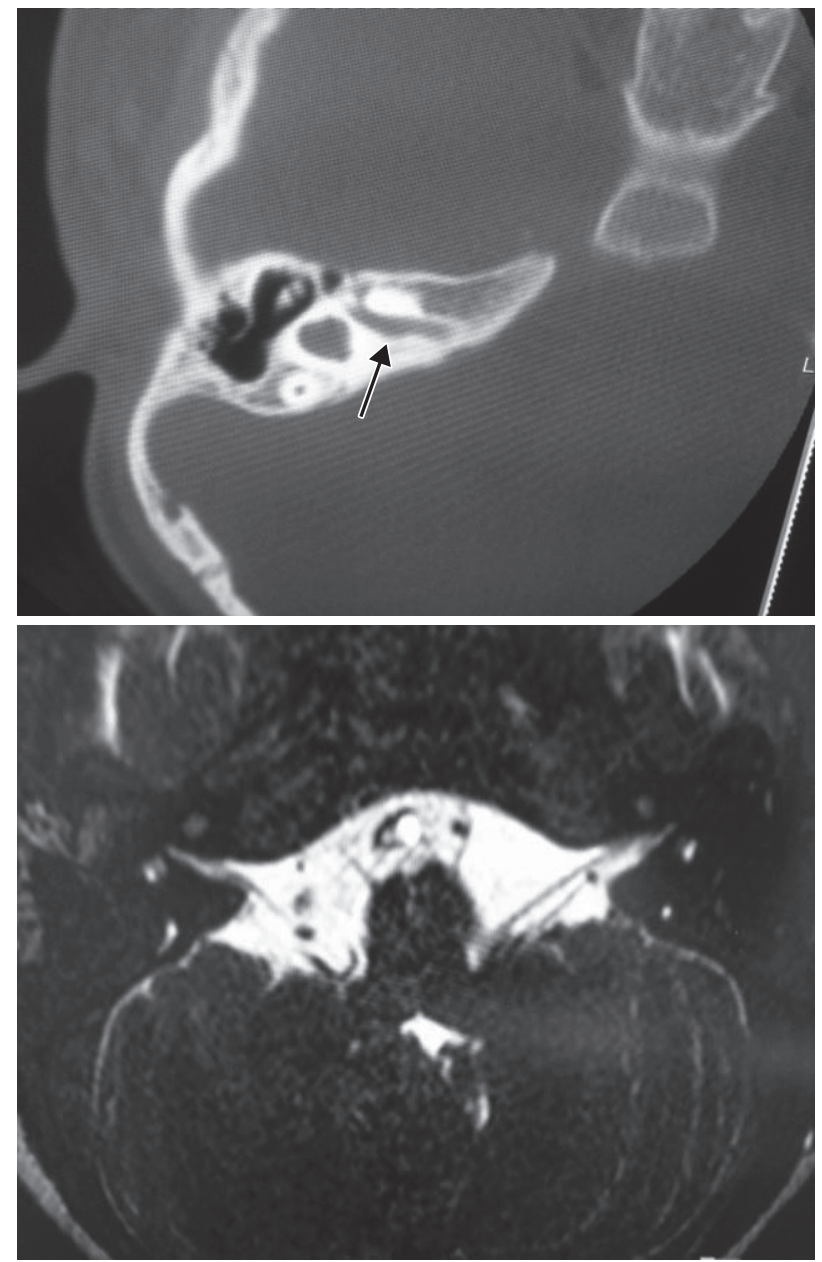

図 2 症例 5 の CT および MR 画像 矢印は内耳道狭窄を示す 


\section{人工内耳植込み術}

手術は全身麻酔下にルーチンの方法 ${ }^{11)} に よ り$ 施行 した．電極はいずれもコクレア社製であり，いずれも 問題なく螖牛内にすべての活性電極が留置された，術 中の NRT およびEABR はいずれの症例も無反応で あった。

\section{手術後の経過}

\section{1 . マップ作成（表 3)}

術後 2 週を目安に音入れを施行したが，当初いずれ も反応がそしく，全症例でパルス幅を広げる必要があ り，刺激レートやマキシマなどのパラメータも変更し ながら, $\mathrm{T} \cdot \mathrm{C} レ$ ルルを設定した，反応を得るために $\mathrm{T}$. Cレベルを上昇させる必要があったが, 症例 1,3 では, 顔面神経刺激反応が認められ，顔面刺激が発生しない ぎりぎりのところでマップを設定した．

特に症例 1 に扔いては, ACE コード化法, パルス 幅 25 では，はっきりとした反応が得られる前に顔面 神経刺激が認められた。顔面神経刺激の出ないぎりぎ りのところでマップを設定するもはじめは日常生活に おいては，反応が全く得られなかった。また，NRT を測定しても波形が得らなかった。マップのパラメー 夕をさまざまな組み合わせで変更したが, SPEAK コード化法で $\mathrm{BP}+1 \sim \mathrm{BP}+6$ に変更しても顕著な反 応が得られなかった。コード化法をCISに変更して も同様であった，ACE コード化法で刺激レートを $1200 \mathrm{~Hz}$ や $1440 \mathrm{~Hz}$ に増やしても反応が改善すること はなかった，最終的には，ACEコード化法，パルス 幅 50 でマップを作成し，不十分ながらも反応が得ら
れるようになった。使用電極は CI $24 \mathrm{M}$ であったが, 電極 7-19に拈いて顔面神経刺激が認められたため, CI24RCS の認可により顔面神経刺激の程度が減少す る可能性についての説明の後, 家族の希望があり, 人 工内耳での反応が左よりも良かった右耳に再手術を施 行した，術後は，語音聴取は難しいが，マッピング時 の反応や聴力検査においては良好な反応を示してい る.

\section{2. 人工内耳での装用闇値}

各症例の人工内耳装用の反応は, 症例 1 では最初の 手術耳（左）では術後 3 カ月での反応は, 閾值 100 $\mathrm{dB}$ 程度とわずかであったが, 術後 1 年経過した段階 でようやく $68 \mathrm{~dB}$ の反応が見られ, 術後 3 年で $50 \mathrm{~dB}$ となっている（図 3)。2 側目（右）は，1側目から 2 年 4 カ月後 $(\nabla)$ に手術したが, 元々補聴器でも反応 が見られていたため, 術後 5 カ月で $46 \mathrm{~dB}$ の反応が 認められ, さらに術後 6 力月後にCI24RCSに再手術し, 右は最初の手術から 1 年後に $40 \mathrm{~dB}, 1$ 年半後には 28 $\mathrm{dB}$ となっている。症例 2 は, 1 側目は術後反応が認 めらなかったため 5 カ月後に電極を抜去し, 対側に手 術したが, 対側は元々補聴器で低音域の反応があった こともあり 7 カ月後に $47 \mathrm{~dB}, 1$ 年半後に $36 \mathrm{~dB}$ の反 応が得られた。症例 3 は, 4 年目まではほぼ反応が見 られず， 4 年半経過したところでようやく $50 \mathrm{~dB}$ 前後 の反応が, 症例 4 も術後 1 年 8 力月頃に $68 \mathrm{~dB}$ の反 応が, 症例 5 も術後 1 年 6 力月後 $50 \mathrm{~dB}$ の反応が認 められ，現在では平均すると 28-46 dB の人工内耳装 用䦐值が得られている (図 3 )。

表 3 各症例のマップの最終状況

\begin{tabular}{|c|c|c|c|c|c|}
\hline 症例 & 術耳 & 使用電極 & コード化法 & パルス幅 & マップ状況（CL） \\
\hline \multirow{2}{*}{1} & 右 & $\mathrm{CI} 24 \mathrm{R}(\mathrm{CS})$ & $\mathrm{ACE}$ & 75 & $\begin{array}{l}\text { マキシマ 8/刺激レート } 720 \mathrm{~Hz} \\
\mathrm{~T} \text { 122-149/C 154-170 }\end{array}$ \\
\hline & 左 & CI24M & ACE & 50 & $\begin{array}{l}\text { マキシマ 8/刺激レート } 500 \mathrm{~Hz} \\
\mathrm{~T} \text { 142-150/C 152-157 }\end{array}$ \\
\hline 2 & 左 & Freedom & $\mathrm{ACE}$ & $75 \cdot 100$ & $\begin{array}{l}\text { マキシマ5/刺激レート } 900 \mathrm{~Hz} \\
\mathrm{~T} \text { 134-183/C 181-202 }\end{array}$ \\
\hline 3 & 左 & Freedom & $\mathrm{ACE}$ & 300 & $\begin{array}{l}\text { マキシマ } 6 \text { / 刺激レート } 250 \mathrm{~Hz} \\
\mathrm{~T} \text { 134-183/C 181-202 }\end{array}$ \\
\hline 4 & 右 & CI422 & $\mathrm{ACE}$ & 200 & $\begin{array}{l}\text { マキシマ 8/刺激レート } 250 \mathrm{~Hz} \\
\mathrm{~T} \text { 140-150/C 168-180 }\end{array}$ \\
\hline 5 & 右 & CI422 & $\mathrm{ACE}$ & 100 & $\begin{array}{l}\text { マキシマ 8/刺激レート } 250 \mathrm{~Hz} \\
\text { T 147-152/C 167-171 }\end{array}$ \\
\hline
\end{tabular}




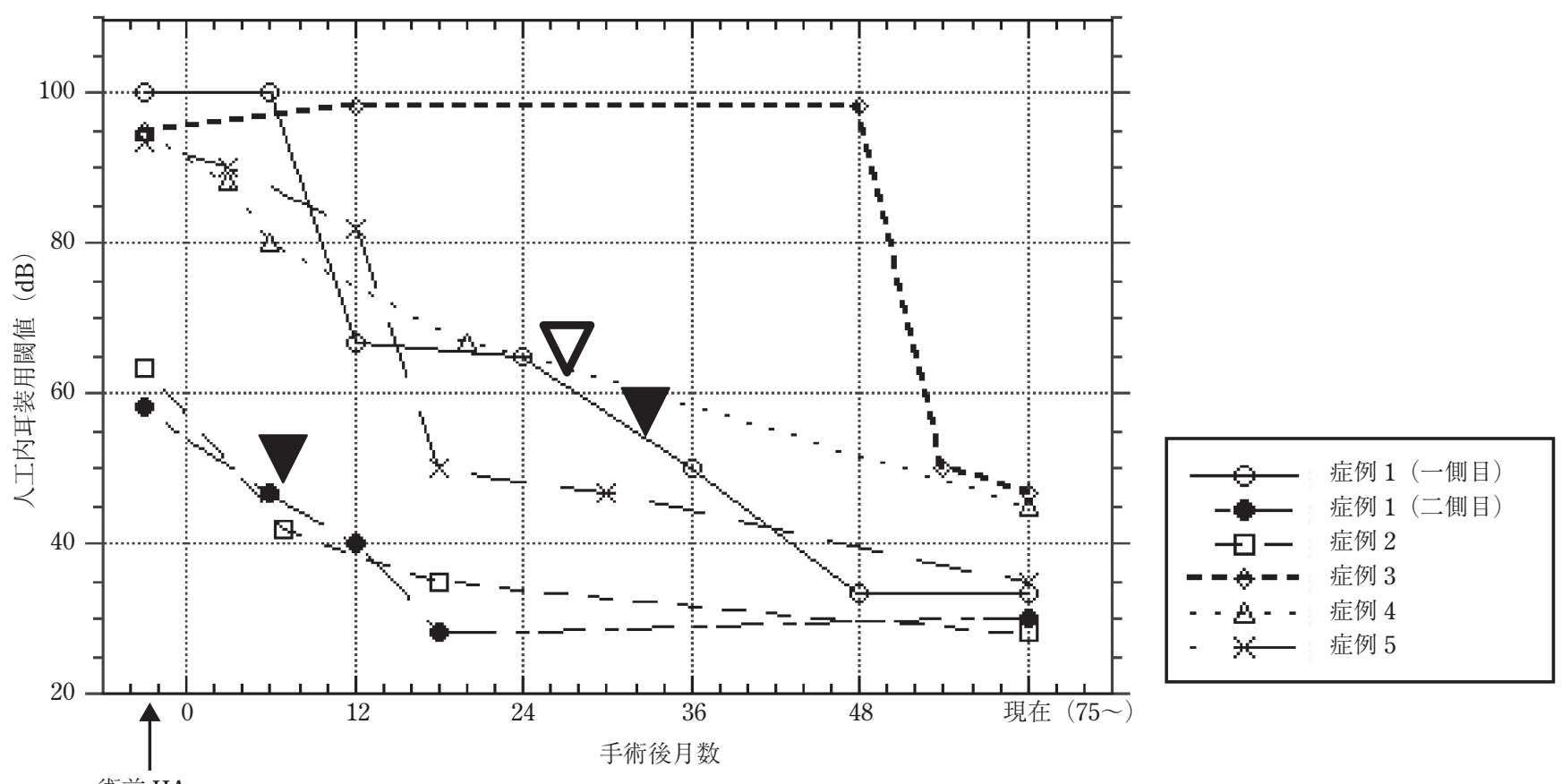

図 3 各症例の CI 装用闇值の推移

$\boldsymbol{\nabla}:$ 症例 1 の二側目 CI24M 手術

$\boldsymbol{\nabla}$ : 症例 1 の二側目を CI24M から CI24RCS へ再手術

表 4 術後聴取・発話・コミュニケーションモード・発達検査の結果

\begin{tabular}{|c|c|c|c|c|c|c|c|c|c|}
\hline 症例 & $\begin{array}{l}\text { IT- } \\
\text { MAIS }\end{array}$ & & & 聴取成績 & $\begin{array}{l}\text { 発話 } \\
\text { 明瞭度 }\end{array}$ & $\begin{array}{l}\text { コミュニ } \\
\text { ケーション } \\
\text { モード }\end{array}$ & $\begin{array}{l}\text { 教育 } \\
\text { 機関 }\end{array}$ & $\begin{array}{l}\text { 発達· } \\
\text { 知能検査 }\end{array}$ & 語彙検査 \\
\hline 1 & - & $67-\mathrm{S}$ & 肉声 $\mathrm{A}$ & $\begin{array}{l}\text { 台 } 20 \% \text { / 左 } 5 \% \text { / 両耳 } 15 \% \\
+\mathrm{V} \text { 両耳 } 40 \%\end{array}$ & 4 & トータル & 聾学校 & $\begin{array}{l}\text { WISC III } \\
\text { PIQ 94/ } \\
\text { VIQ } 56\end{array}$ & $\begin{array}{l}\text { PVT-R 12: } 10 \text { 歳時, } \\
\text { 語彙年齢 } 7: 0 \text { 歳 }\end{array}$ \\
\hline 2 & - & $67-\mathrm{S}$ & CD 5\% & 肉声 A $20 / A+V 60 \%$ & 3 & トータル & 聾学校 & $\begin{array}{l}\text { 新版 K 式 } \\
\text { 認知 } 83 / \\
\text { 言語 } 60\end{array}$ & $\begin{array}{l}\text { PVT-R 9:8 歳時, } \\
\text { 語彙年齢 } 7: 3 \text { 歳 }\end{array}$ \\
\hline 3 & - & $67-\mathrm{S}$ & & 肉声 A 0\%/A+V 35\% & 4 & トータル & 聾学校 & $\begin{array}{l}\text { 新版 K 式 } \\
\text { 認知 } 127 / \\
\text { 言語 } 65\end{array}$ & $\begin{array}{l}\text { PVT-R 8: } 4 \text { 歳時, } \\
\text { 語彙年齢 } 5: 8 \text { 歳 }\end{array}$ \\
\hline 4 & 24 & & & 検査不可 & 4 & トータル & 聾学校 & $\begin{array}{l}\text { 新版 K 式 } \\
\text { 認知 } 109 / \\
\text { 言語 } 86\end{array}$ & $\begin{array}{l}\text { PVT-R } 7: 1 \text { 歳時, } \\
\text { 語彙年齢 } 3: 2 \text { 歳 }\end{array}$ \\
\hline 5 & 30 & & & 検査不可 & 5 & トータル & 畆学校 & $\begin{array}{l}\text { 新版 K 式 } \\
\text { 認知 } 59 / \\
\text { 言語 } 23\end{array}$ & $\begin{array}{l}\text { マッカーサー： } \\
\text { 理解 (手話) } 165 \text { 語 / } \\
\text { 表出 (手話) } 22 \text { 語 }\end{array}$ \\
\hline
\end{tabular}

3．聴取・発話・コミュニケーションモード・教育 機関などの経過（表 4）

現在, 聴取成績は, 症例 $1 \sim 3$ で $67-\mathrm{S}$ 語表では肉 声 $\mathrm{A}$ のみで 5-20\%であり，発話明瞭度も 3-4である. 症例 4, 5 はIT-MAIS で 24 と 30 であるが，聴取検 査はできていない，また，発話明瞭度も 4-5 と不良で あった。コミュニケーションモードは全症例でトータ
ルコミュニケーション，教育機関は全症例で聴覚特別 支援学校であった。しかし，いずれの養育者も手術を 行ったことに対しては否定的ではなく，聴覚から多少 なりとも音刺激が入ることを，手話の補助として有効 であるとして，環境音は認識できる症例も多く，危険 を回避できる可能性があることなどを含め評価してい た。 


\section{4. 認知発達および語彙発達（表 4)}

症例 1 は, WISC IIIにてPIQ 94, VIQ 56, 症例 2 〜 4 は新版 $\mathrm{K}$ 式の認知 83-127 と認知発達は特に問題 なく, 言語は 60-86 と症例 4 を除いて言語発達の遅れ が認められた。症例 5 はダウン症もあり, 新版 $\mathrm{K}$ 式 の認知 59 , 言語 23 と認知発達の遅れもが認められた。

語彙でも PVT-R では, 症例 1 で約 6 年, 症例 $2 \sim 4$ では 2〜4 年の遅れが認められた。

\section{考察}

\section{ICS と難聴}

内耳道は発生学的に, 螖牛, 前庭神経を囲む中胚葉 が神経周囲で骨化することによって形成される，胎生 3 週に体表外胚葉から形成された耳板が陥凹して, 胎 生 4 週に耳胞を形成, 胎生 9 週に耳胞周囲の小細胞群 から螖牛前庭神経節が形成され，さらにその周囲を囲 む中胚葉が内耳道を形成する ${ }^{12)}$. 内耳道の長さはその 後も胎内で増大が見られ, 胎生 24 週には完成するが, 径はあまり変化しないとされている1314). ICS は, 蝸 牛前庭神経の形成不全による二次的なものと考元ら $れ^{15)}$ ，一側性 ICS の報告は散見されるが16,17)，両側 ICS はきわめてまれであるとされている ${ }^{18)}$ ，側頭骨 CT では内耳道の狭窄として確認され，径 $1.3 \sim 1.5$ $\mathrm{mm}$ 以下を異常とする報告がある ${ }^{19)}$.またしばしば, 蝸牛神経欠損 (cochlear nerve deficiency, 以下 CND）と同義に報告している場合もあるが ${ }^{10,20)}$ ，仮に 画像検査で蝸牛神経が確認されなくとも, 音反応が認 められた場合には, CND より ICSの診断が理にかなっ ているといえよう。

Adunka ${ }^{21)}$ は新生児聴覚スクリーニングで発見さ れる難聴児の $1 \%$ はND であると推測している。わ れわれの先天性小児重度難聴児 298 例中の内耳形態異 常は 28 例 $(9.5 \%)$ に見られ，そのうちの ICSは 5 例 (1.7\%) にすぎなかった。また，CND 症例は，臨床 的には auditory neuropathy spectrum disorder（以下 ANSD）の所見を呈する症例があり，ANSDの $20 \%$ は CND であると報告されている ${ }^{19)}$ 。一方, 重度難聴 を示さない ICSもある22,23). Phelps ら ${ }^{24)}$ は画像上直 径 $3 \mathrm{~mm}$ 以下の内耳道を有する症例には, すべてに さまざまな程度の感音難聴が認められたと報告してお り, 内耳道狭窄のみではなく, 蝸牛神経の成熟の程度 により難聴の程度が変わる可能性を示唆している。今 回われわれはこれを参考に前後径が，内耳道内側部， 中間部，入口部のいずれかで $3 \mathrm{~mm}$ 以下を ICS とし て検討した。

\section{ICS に対する人工内耳植込み術の適応判断}

Shelton $ら^{8)}$ は 3 例の ICS 例（他の内耳奇形なし） に人工内耳埋込み術を行ったが音知覚を得ることがで きなかったため，本疾患を人工内耳の禁忌とした，以 来, ICS はしばしば人工内耳の適応から除外されてき た.しかし，近年 MRIの進歩により内耳道内の蝸牛 神経が同定できるようになり ${ }^{25)}$, Acker ら ${ }^{26)}$ は両側 ICS 例に対して, MRIで蝸牛神経が同定できた側に 人工内耳埋込み術を施行し，音知覚を得たため, ICS でも MRIで螖牛神経が確認できれば人工内耳の適応 があると報告している.

一方, Nelson $5^{15)}$ は, 側頭骨の解剖から正常内耳 道においても蝸牛神経の無形成が起こりうるので，人 工内耳植达み術を施行するにあたっては MRI 検査が 必須であると報告している。同様に, Sennaroglu ら ${ }^{27)}$ も正常 CT を示す先天䆍の患者のなかには, 蝸 牛神経の無形成のケースもありうることを念頭におい て MRI を施行するよう推奨している.

われわれの症例では，MRI 検査にて 3 症例 5 耳の 内耳道内神経の描出が不明であった。ささらに人工内耳 植达み術の適応に他覚的聴力検查で反応があることの 報告もあるが9,28)，われわれの症例のうち 1 症例では ABRやASSR もほとんど反応が見られなかった。 ICSでは，内耳道の 4 本の神経のうちいずれか，また はいずれも狭窄または欠損している可能性がある。今 回の症例では, 症例 3 以外は顔面神経麻痺を認めてい ないので，それらでは少なくとも顔面神経の異常はな いと考えられる。また，球形囊神経，つまり下前庭神 経は音に反応することがあるが29,30)，この場合には $800 \mathrm{~Hz}$ 以下の低周波数帯域の $80 \mathrm{~dB}$ 以上の巨大音で ある。今回の 5 症例はいずれも, 3 歳前という時期に あっても補聴器にて, 特に中周波数帯域から高周波数 帯域にかけての聴覚反応がある程度認められたので, 蝸牛神経も狭窄はあっても欠損はないと判断できたこ とにより，いずれも人工内耳植込み術施行にいたった。 その結果として長期間掛かったとはいえ人工内耳を介 した音刺激による反応が見られていることから，多少 なりとも補聴器などで聴覚反応があれば contraindicationではないと考えられる.

しかし，現実的には患児およびその養育者にとって， 人工内耳の手術をして半年以上（今回の最長は症例 4 の 4 年）も，明らかな反応が見られないことへの精神 的負担はかなり大きいといえ，実際にわれわれの症例 2 のように電極抜去にいたるケースもあり，反応がす ぐには出ない可能性があること，その間も持続的な人 
工内耳装用による電気刺激が必須であることの養育者 への十分なインフォームドコンセントが不可欠といえ る。実際，初期の症例である症例 1 では，反応が出る のに長期を要することの説明は十分とはいえない可能 性があるし, 症例 2 でも最初の手術時である右は残し て刺激を加えるということについて，もう少し強くイ ンフォームドコンセントすることが必要であったと考 えられる。

\section{3．マップの術後経過}

内耳形態異常がない通常の重度難聴児へのコクレア 社製人工内耳のマッピングでは，デフォルトのパラ メータは, コード化法が ACE，パルス幅は 25 または 37, マキシマ 8, 刺激レート $900 \mathrm{~Hz}$ で, 電圧追従性 ラインを超えない範囲で TC レベルの設定が可能であ る。今回の ICS 症例では, すべての症例でパラメー 夕を変更し, パルス幅を広げて刺激電荷量を増やす必 要があった。症例 1 でコード化法やパルス幅などのパ ラメータを変更し検証した経験により，その後の他症 例のマップ作成に打いて, パラメータの選択の検討や その後の予測に役立つことが多かった，最長で音刺激 が得られるまでに 4 年半を要した症例も見られたが, 刺激を与え続けることで, 螖牛神経から中枢において 徐々に活性化され音知覚につながったと考えられる。

\section{4. 術後経過として装用閾値}

各症例の人工内耳装用の反応は, 症例 1,2 は 2 側 目の手術で早々に反応が見られたが，症例 4,5 では $1 \sim 2$ 年, 症例 3 においては 4 年以上明らかな反応が 認められなかった。そして，現在はいずれも，500 $\mathrm{Hz}$ から 2,000 Hz までの 4 分法平均で 28〜 46 dB の装 用闇值が得られており，ICS 例でもある程度十分な装 用闇值が得られることがわかった。しかし，その音反 応を得るまでにかなりの時間を要したことは，人工内 耳を介した電気刺激量が十分でなかったことも考えら れるが，螖牛神経から中枢への神経の活性化にはある 程度時間が掛かることが大きいと考えられる。

この意味では，ICS だからこそ早期に人工内耳植込 み術を施行し電気刺激を行うこと, 適切な電気刺激を するための早期のマップ作成が重要なポイントといえ よう.

\section{5. 聴取・発話・発達などについて}

音知覚は継続した人工内耳を介した刺激により得ら れたとはいえ, 術後成績としての聴取能, 発話明瞭度 などは良好とはいえない，また，コミュニケーション モードは全症例でトータルコミュニケーション, 教育 機関は，全症例が聴覚特別支援学校であり，人工内耳
を介した聴覚のみでのコミュニケーションのみでは会 話は難しく, 手話が中心となっていた。このことは, 従来の報告9, 10) と同様に, ICS ではインフォームドコ ンセントも含めて慎重であるべきことと矛盾するもの ではない，われわれの就学時の小児の聴取や学習能力 を検討したところ, 聴取に比べ学習能力が低い例が 10\%ほど存在した，その理由はさまざまであるが，そ のなかに ICS 例が存在するのも確かといえよう.

とはいえ一方, 養育者も聴覚から多少なりとも音刺 激が入ることを，手話の補助として有効であると判断 しており，ICSでは他の内耳形態異常 ${ }^{20)}$ と同様に人工 内耳のみでの会話は難しくとも，手話を併用したコ ミュニケーションモードを活用したうえで，装用児の 言語発達に貢献できるといえるので, contraindication とはいえないと考えられる。

\section{ま と め}

1.内耳道狭窄を伴う人工内耳装用 5 症例について 検討した。

2. マップでは全症例でパラメータを変更し電荷量 を増やす必要があった。

3. 全症例で音知覚が得られたが, 反応が出るまで に長期間を要する者が多く, 最長で 4 年半掛かった.

4. 全症例で語音聴取は不良であり, トータルコ ミュニケーションを使用していた．

5. 術前に聴覚反応があれば人工内耳の適応と考え られた。

6. 人工内耳植込み術にあたっては，反応が見られ るまでに時間が掛かること, 術後反応不良の可能性が あること，人工内耳を介した会話には限界があること などの術前の十分なインフォームドコンセントと術後 早期の適切なマップ作成が必要である.

本報告に执ける開示すべき利益相反（COI）関係にある企業. 団体等はない.

\section{文献}

1) 平海晴一, 伊藤壽一: 乳幼児の人工内耳の術後成績. JOHNS, 24:1451-1454, 2008.

2) Uziel AS, Sillon M, Vieu A, et al: Ten-year follow-up of a consecutive series of children with multichannel cochlear implants. Otol Neurotol, 28: 615-628, 2007.

3）本庄 㦑, 金子敏郎, 坂井 真, 他: 人工内耳適応基準に ついて. 日耳鼻, $101: 860-861,1998$.

4）三浦 誠, 坂本達則, 平海晴一, 他: 小児内耳奇形例の人 工内耳手術. Otology Japan, 18:625-630, 2008.

5) Papsin BC: Cochlear implantation in children with 
anomalous chochleovestibular anatomy. Laryngoscope, 115: 1-26, 2005.

6) Sennaroglu L and Saatci I: A new classification of cochleovestibular malformations. Laryngoscope, 112: 2230-2241, 2002.

7) Sennaroglu L and Saatci I: Unpartitioned versus incompletely partitioned cochleae: Radiologic differentiation. Otol Neurotol, 25: 520-529, 2005.

8) Shelton C, Luxford WM., Tonokawa LL, et al: The narrow internal auditory canal in children: a contaraindication to cochlear implants. Otolaryngol Head Neck Surg, 100: 227-231, 1989.

9）高橋優宏, 熊川孝三, 武田英彦, 他: 人工内耳埋め込みが 有効であった両側内耳道狭窄の 1 症例. Otology Japan, $14: 248-251,2004$.

10) Glastonbury CM, Davidson HC, Harnsberger HR, et al: Imaging findings of cochlear nerve deficiency. Am J Neuroradiol, 23: 635-643, 2002.

11）河野 淳：人工内耳の手術. 日耳鼻, 119 (2)：99-109, 2016.

12) Yates JA, Patel PC, Millman B, et al: Isolatedcongenital internal auditory canal atresia with normal facial nerve function. Int J Ped Otolaryngol, 41: 1-8, 1997.

13) Portmann M: Anatomy. The Internal Auditory Meatus: Anatomy, Pathology, and Surgery (edited by Portmann M, Sterkers JM, Charachon R, et al), Churchill Livingstone, Edinburgh, pp 3-52, 1975.

14) Sakashita $T$ and Sando I: Postnatal development of the internal auditory canal studied by computer-aided threedimensional reconstruction and measurement. Ann Otol Rhinol Laryngol, 104: 469-475, 1995.

15) Nelson EG and Hinojosa R: Aplasia of the cochlear nerve: a temporal bone study. Otol Neurotol, 22: 790-795, 2001.

16) Ito $K$, Ishimoto $S$ and Murofushi $T$ : Narrow internal auditory meatus: an idiopathic case confirming the origin and pathway of vestibular evoked myogenic potentials in human. Arch Otolaryngol Head Neck Surgery, 127: 275278, 2001.

17) Molter DW, Pate BR and Mcelveen JT: Cochlear implantation in the congenitally malformed ear. Otolaryngol Head Neck Surgery, 108: 174-177, 1993.

18) Camacho RR, Berrocal JRG and Arellano B: Bilateral malformation of the internal auditory canal: Atresia and contralateral transeverse megacrest. Otolaryngol Head
Neck Surgery, 125: 115-116, 2001

19) Roche JP, Huang BY, Castillo $M$, et al: Imaging characteristics of children with auditory neuropathy spectrum disorder. Otol Neurotol, 31: 780-788, 2010.

20）諸頭三郎, 山崎博司, 内藤 泰, 他：内耳奇形を伴う小児 人工内耳症例の術後成績, Audiology Japan, $55: 68-76$, 2012.

21) Adunka OF, Roush PA, Teagle HFB, et al: Internal auditory canal morphology in children with cochlear nervedeficiency. Otol Neurotol, 27: 793-780, 2006.

22）斎藤秀行, 小川 郁, 井上泰宏, 他 : 特発性内耳道狭窄の 2 症例. Otology Japan, 6:556-561, 1996.

23）仲野敦子, 有本友季子, 松永達雄, 他：側頭骨 CT で両側 蝸牛神経管狭窄を認めた小児難聴症例の検討。日耳鼻, $115: 849-854,2012$.

24) Phelps PD, Lloyd GAS and Sheldon PWE: Deformity of labyrinth and internal auditory meatus in congenital deafness. Br J Radiol, 48: 973-978, 1975.

25) Casselman JW, Offeciers FE, Govaerts PJ, et al: Aplasia and hypoplasia of the vestibulocochlear nerve: Diagnosis with MR imaging. Radiology, 202: 773-781, 1997.

26) Acker T, Mathur NN, Savy L, et al: Is there a functioning vestibulocochlear nerve? Cochlear implantation in a child symmetrical auditory findings but asymmetrical imaging. Int J Ped Otolaryngol, 57: 171-176, 2001.

27) Sennaroglu L, Saatci I, Aralasmak A, et al: Magnetic resonance imaging versus computed tomography in preoperative of cochlear implant candidates with congenital hearing loss. J Laryngol Otol, 116: 804-810, 2002.

28) Nikolopoulos TP, Mason SM, Gibbin KP, et al: The prognostic value of promontory electric auditory brain stem response in pediatric cochlear implantation. Ear Hear, 21: 236-241, 2000.

29) McCue MP and Guinan JJ Jr: Acoustically responsive fibers in the vestibular nerve of the cat. J Neurosci, 14: 6058-6070, 1994.

30) Murofushi T, Curthoys IS, Topple AN, et al: Responses of guinea pig primary vestibular neurons to clicks. Exp Brain Res, 103: 174-178, 1995.

別刷請求先：=160-0032 東京都新宿区西新宿 6-7-1 東京医科大学耳鼻咽喉科 - 頭頸部外科学分野 富澤文子 